\author{
BoŻENA TAŃSKA-Hus ${ }^{1}$
}

\title{
Renty strukturalne jako instrument poprawy struktury obszarowej rolnictwa i przyspieszenia wymiany pokoleń
}

\section{Uregulowania prawne $w$ zakresie rent strukturalnych w UE}

Jednym z celów Wspólnej Polityki Rolnej Unii Europejskiej jest poprawa struktury obszarowej i przemiany pokoleniowe w rolnictwie. Cel ten został wprowadzony do polityki w ramach tzw. reform McScharry'ego w 1962 r. Przemianom tym sprzyjało rozporządzenie Rady (WE) nr 2079/1992 z dnia 30 czerwca 1992 r. w sprawie środków pomocy dla rolników przechodzących na wcześniejszą emeryturę, ${ }^{2}$ zastąpione później rozporządzeniem nr 1257/1999 z dnia 17 maja 1999 r. w sprawie wsparcia rozwoju obszarów wiejskich z Europejskiego Funduszu Orientacji i Gwarancji Rolnej (EFOGR) oraz zmieniające i uchylające niektóre rozporządzenia. ${ }^{3}$ Oba te akty miały na celu umożliwienie państwom członkowskim tworzenia programów wcześniejszych emerytur „strukturalnych” współfinansowanych z budżetu Unii Europejskiej. Choć sam udział państw członkowskich w programie był oparty na zasadzie dobrowolności, to jednak gdy któreś z nich zdecydowało się wprowadzić świadczenia strukturalne, zobowiązane było dostosować własne ustawodawstwo do unormowań powoływanych rozporządzeń w celu uzyskania środków finansowych z Funduszu Orientacji i Gwarancji Rolnictwa (FEOGA).

Do głównych celów unijnego programu emerytur strukturalnych w rolnictwie należy zachęcenie do wcześniejszego zaprzestania prowadzenia działalności rolniczej przez rolników w wieku przedemerytalnym na rzecz młodych rolników lepiej wykwalifikowanych. Zadbano jednocześnie o zapewnienie odpowiednich dochodów starszym rolnikom, którzy postanowili przystąpić do programu. Kładąc nacisk na rentowość działalności, umożliwiono przekazanie do zagospodarowania pozarolniczego gruntów, których rolnicze użytkowanie nie jest opłacalne. 
Renty strukturalne jako instrument poprawy struktury obszarowej rolnictwa...

Ze względu na to, iż rozporządzenie Rady nr $1257 / 99$ nie wprowadziło aż tak istotnych modyfikacji, aby konieczne stało się dokonanie gruntownych przekształceń już istniejących krajowych programów emerytur strukturalnych, omówione zostaną tu regulacje zawarte w rozporządzeniu nr 2079/92, które stanowiły podstawę dla zorganizowania owych programów.

Część unormowań zawartych w rozporządzeniu nr 2079/92 wiązała państwa i nie mogła być przez nie zmieniona, w niektórych kwestiach pozostawiono zaś pewną swobodę wyboru. Do tych pierwszych należały przepisy uzależniające nabycie prawa do wcześniejszej emerytury od zaprzestania działalności rolniczej i odpowiedniego rozdysponowania gruntów na rzecz osób trzecich. Określono także, że rolnik, który chciał przekazać gospodarstwo rolne musiał być w wieku przedemerytalnym, przy jednoczesnym ukończeniu 55 lat, a prowadzona przez niego działalność rolnicza stanowiła jego główne źródło dochodu przez ostatnie 10 lat. Przyjęcie gospodarstwa rolnego powinno nastąpić na cele związane z produkcją rolną, a przejmujący miał mieć odpowiednie kwalifikacje rolnicze oraz był zobowiązany do wykonywania działalności rolniczej (jako główne źródło dochodu) przez co najmniej 5 lat od przejęcia gruntów. Gdy przejęcie miało nastąpić na cele nierolnicze, przy użytkowaniu gruntów trzeba było zachować wymogi ochrony środowiska. ${ }^{4}$

Określenie minimalnej normy obszarowej nowo powstałego gospodarstwa leżało w gestii państw członkowskich, jednakże jego wielkość powinna umożliwiać poprawę kondycji ekonomicznej. Pozostawiono swobodzie także wybór świadczeń związanych z wcześniejszym przejściem na emeryturę, określając jedynie ogólny ich katalog:

- premia odejścia - jednorazowa wypłata z tytułu wcześniejszego przejścia na emeryturę;

- roczna renta niezależnie od obszaru przekazanych gruntów;

- roczna renta od hektara przekazanych gruntów;

- dodatek do emerytury wypłacanej zgodnie z wewnętrznym systemem emerytalnym państw członkowskich. ${ }^{5}$

W rozporządzeniu określono maksymalny okres wypłaty świadczeń strukturalnych na 10 lat, lecz nie dłużej niż do osiągnięcia przez świadczeniobiorcę 70 lat (w rozporządzeniu z 1999 - 75 lat).

Każdy z programów opracowanych przez państwa członkowskie wymagał zatwierdzenia przez Komisję Europejską. Współfinansowanie z FEOGA zatwierdzo-

\footnotetext{
4 B. Tańska-Hus, M. Orlewski, Koncepcje wcześniejszych emerytur rolniczych w krajach UE i w Polsce jako instrument poprawy struktury agrarnej i przyspieszenia wymiany pokoleń, „Acta Scientiarum Polonorum Oeconomia” 2002, nr 1-2, s. 126. 
nych programów wynosiło od 50\% do $75 \%$, przy czym UE współuczestniczyła również w kosztach administracyjnych związanych z obsługą systemu. W oparciu o rozporządzenie z 1992 r. funkcjonowało 10 systemów wcześniejszych emerytur w rolnictwie ustanowionych przez państwa członkowskie, z tym że Hiszpania i Portugalia realizowały również specjalne programy regionalne.

Doświadczenia państw członkowskich Unii Europejskiej wykazywały pewne trudności we wdrożeniu programu wcześniejszych emerytur. Ze względu na znaczne odrębności każdy kraj musiał wypracować pewne indywidualne rozwiązania, zgodne jednakże z rozporządzeniem. Tym niemniej, przykładowo, we Francji wprowadzenie programu przyniosło pozytywne rezultaty, gdyż ponad $51 \%$ uwolnionej powierzchni objęli rolnicy młodzi, a około $21 \%$ gruntów przeznaczono na powiększenie gospodarstw już działających. Program zachęcił francuskich rolników głównie do przekazywania ziemi w ramach rodziny (75\%). W Irlandii natomiast średnia powierzchnia gospodarstwa wzrosła do poziomu 20 hektarów, a średni wiek rolników obniżył się do 50 lat. Rocznie przekazywano około 5500 gospodarstw. Hiszpański program wcześniejszych emerytur strukturalnych nie spotkał się z tak przychylnym przyjęciem, gdyż liczba przekazujących swe gospodarstwa nie przekroczyła 1000 osób rocznie. Stosunek rolników do zaoferowanego świadczenia różnił się zatem znacznie w poszczególnych państwach. Wynikało to przede wszystkim z wysokości emerytur strukturalnych, choć nie bez znaczenia pozostawały również możliwe sposoby zaprzestania działalności rolniczej czy przywiązanie do zawodu i związanego z nim sposobu życia. ${ }^{6}$

Należy zaznaczyć, że generalnie znaczna część rozwiązań w poszczególnych krajowych programach państw UE opracowanych na podstawie tych rozporządzeń była ukształtowana podobnie. Było to konsekwencją przepisów iuris cogentis rozporządzeń, gdyż w tym zakresie unormowania państw członkowskich powinny być dokładnym odzwierciedleniem postanowień rozporządzeń. Różnice dotyczyły przepisów dyspozytywnych, a w szczególności minimalnego obszaru uprawniającego do przystąpienia do programu, wieku osób uprawnionych do korzystania z renty, wysokości świadczeń, dodatków obszarowych.

W latach 2007-2013 podstawą funkcjonowania wcześniejszych emerytur rolniczych w ramach prawa wspólnotowego jest rozporządzenie Rady nr 1698/2005 z dnia 20 września 2005 r. w sprawie wsparcia rozwoju obszarów wiejskich przez Europejski Fundusz Rolny na rzecz Rozwoju Obszarów Wiejskich. ${ }^{7}$ Podstawowym celem nowych rent jest zmiana struktury agrarnej poprzez zachęcenie do przekazyi przyspieszenia wymiany pokoleń, „Roczniki Naukowe SERiA” 2003, t. 5, 2,4, s. 341. 
Renty strukturalne jako instrument poprawy struktury obszarowej rolnictwa...

wania gospodarstw na rzecz młodych rolników oraz poprzez przekazywanie gospodarstw na powiększenie już istniejących jednostek produkcyjnych.

Zgodnie z rozporządzeniem pomoc przewidziana jest dla rolników oraz robotników rolnych, jeżeli zdecydują się na zaprzestanie aktywności zawodowej w rolnictwie. Rolnicy mogą skorzystać ze świadczeń, jeżeli ukończyli 55 lat, ale nie osiągnęli wieku emerytalnego albo mają nie mniej niż 10 lat do osiągnięcia normalnego wieku emerytalnego, i prowadzili działalność rolniczą co najmniej 10 lat poprzedzających przekazanie.

Przejmującym może być osoba spełniająca kryteria pomocy dla młodego rolnika lub rolnik, który osiągną 50 lat. Może być to także osoba prawna lub jednostka organizacyjna nieposiadająca osobowości prawnej. Poza młodymi rolnikami przejęcie powinno nastąpić w celu powiększenia istniejącego gospodarstwa rolnego.

Okres wypłaty emerytury nie może przekroczyć 15 lat, nie później jednak niż do ukończenia przez przekazującego 70. roku życia. Jeżeli przekazujący otrzymał prawo do świadczeń emerytalnych z ubezpieczenia społecznego, to wcześniejszą emeryturę wypłaca się jako dodatek (nadwyżka nad świadczeniami z ubezpieczenia). Roczną wartość świadczenia ustalono na poziomie maksymalnym 18 tys. euro, całość 180 tys. euro na przekazującego.

Porównując obecnie obowiązujące przepisy w stosunku do rozporządzenia z 1999 roku można stwierdzić, że nastąpiło przeniesienie akcentu z zapewnienia dochodu starszym rolnikom (art. 11 ust. 1 rozporządzenia z 1999 r.) na zaprzestanie działalności rolniczej i przekazanie gospodarstwa innym rolnikom (art. 23 ust. 1 lit. a rozporządzenia z 2005 r.). Ponadto w nieobowiązującej już regulacji dopuszczono wsparcie dla osób między 55. rokiem życia a wiekiem emerytalnym, obecnie dodano zapis bardziej elastyczny dla tego przedziału wieku, a mianowicie: [...] nie więcej niż 10 lat mniej niż wymagane dla normalnego wieku emerytalnego [...]. Od beneficjenta wymaga się prowadzenia działalności rolniczej przez ostatnie 10 lat, a poprzednio wskazywano na konieczność prowadzenia gospodarstwa rolnego w takim samym okresie. Odmiennie uregulowano także warunki dla przejmującego grunty. W aktualnym stanie prawnym dopuszczono nabycie między innymi przez młodego rolnika, czyli osobę, która nie ukończyła 40 lat i spełniającą pozostałe przesłanki, w tym przedkładającą plan dotyczący rozwoju działalności rolniczej oraz przez rolnika - osobę fizyczną prowadzącą już gospodarstwo i która nie ukończyła 50 lat. Tej granicy wiekowej wcześniej nie określono.

Ponadto odmiennie w obu porządkach prawnych unormowano całkowity okres wsparcia. Na mocy przepisów z 2005 roku wsparcie nie przekracza 15 lat zarówno dla rolników, jak i robotników rolnych poprzednio w tej ostatniej sytuacji - maksimum 10 lat. Dotychczas świadczenia wypłacano do ukończenia przez rolników 75. roku życia, a obecnie do 70 lat. 
Zmianie uległ także system finansowania programu rent strukturalnych. W przepisach z 1999 r. były one finansowane z Sekcji Gwarancji EFOiGR, natomiast od 2007 r. środki pochodzą z Europejskiego Funduszu Rolnego na rzecz Rozwoju Obszarów Wiejskich.

\section{Uregulowania prawne w zakresie rent strukturalnych w Polsce}

Pierwsze koncepcje systemu wcześniejszych emerytur strukturalnych w rolnictwie polskim pojawiły się w przyjętej przez Radę Ministrów 21 kwietnia $1998 \mathrm{r}$. Średniookresowej strategii rozwoju rolnictwa i obszarów wiejskich. ${ }^{8} \mathrm{Na}$ jej podstawie minister właściwy do spraw rolnictwa i rozwoju wsi opracował 30 czerwca 1998 r. Wstępne założenia programu wcześniejszych emerytur strukturalnych $w$ rolnictwie, zawierające wiele propozycji dotyczących przyszłego programu. Zasadniczym celem programu było przede wszystkim poprawienie struktury obszarowej gospodarstw, celem wtórnym natomiast zabezpieczenie socjalne dla rolników - uczestników programu. Założono, że efektem strukturalnym będzie wzrost liczby gospodarstw powyżej 15 ha, osiągnięty dzięki zwalnianiu gruntów przez rolników objętych programem na rzecz rolników młodych i wykwalifikowanych.

Etap dyskusji nad kształtem przyszłego programu wcześniejszych emerytur rolniczych zakończył się 13 lipca 1999 r. przyjęciem dokumentu Spójna polityka strukturalna rozwoju obszarów wiejskich i rolnictwa. Określał on działania rządu w zakresie aspektów strukturalnych rozwoju obszarów wiejskich na okres najbliższych kilku lat. Z jego treści wynikało, że system świadczeń emerytalnych opracowany na podstawie rozwiązań stosowanych w Unii Europejskiej uzupełni system wcześniejszych emerytur zawarty w ustawie z 20 grudnia 1990 r. o ubezpieczeniu społecznym rolników. Dlatego też w opracowanym projekcie ustawy o świadczeniach strukturalnych zaproponowano zmianę nazwy świadczenia na renta, gdyż w powszechnej świadomości pojęcie emerytura kojarzone jest ze świadczeniami z ubezpieczenia społecznego.

1 stycznia 2002 r. weszła w życie ustawa z dnia 26 kwietnia 2001 r. o rentach strukturalnych $\mathrm{w}$ rolnictwie. ${ }^{9}$ Zgodnie $\mathrm{z}$ art. 3 ust. 1 ustawy, prawo do renty strukturalnej mógł nabyć rolnik w wieku 60-65 lat (mężczyzna) lub 55-60 lat (kobieta), który zaprzestał prowadzenia działalności rolniczej, podlegał ubezpieczeniu społecznemu rolników przez okres 120 kwartałów oraz przez 10 lat bezpośrednio przed zagłoszeniem wniosku o rentę strukturalną prowadził nieprzerwanie działalność rolniczą, która stanowiła jego jedyne lub główne źródło dochodów (wymagania dotyczące rolnika miały zastosowanie odpowiednio do jego małżonka). 
Renty strukturalne jako instrument poprawy struktury obszarowej rolnictwa...

Zgodnie z ustawą przekazaniu ulec mogło jedynie gospodarstwo o minimalnej powierzchni 3 hektarów, które przez co najmniej ostatnich 5 lat przed zgłoszeniem przez rolnika wniosku o przyznanie świadczeń strukturalnych stanowiło jego własność, własność jego małżonka lub współwłasność obojga małżonków (art. 3, ust. $3)$.

Ustawa określała również wymagania dotyczące formy przekazania oraz osoby przejmujące gospodarstwo rolne. Przekazanie gospodarstwa mogło nastąpić odpłatnie lub za darmo w drodze umowy na rzecz osoby fizycznej, a także osoby prawnej lub jednostki organizacyjnej niemającej osobowości prawnej - jeżeli działalność rolnicza należała do zakresu ich działania. Umowa, poza wymaganiami zawartymi w odrębnych przepisach, powinna zawierać oświadczenia stron wraz z zapewnieniem o przekazaniu gospodarstwa na powiększenie jednego lub kilku już istniejących gospodarstw rolnych oraz o tym, że powierzchnia powiększonego w ten sposób gospodarstwa nie jest mniejsza niż 15 hektarów, także oświadczenia stron co do spełnienia warunków w stosunku do osoby przejmującej (art. 7, ust. 1). Przejmującym mógł być rolnik, który nie miał ustalonego prawa do świadczeń emerytalnorentowych z ubezpieczenia lub zaopatrzenia społecznego oraz ma kwalifikacje rolnicze.

Ustawa dopuszczała jednocześnie możliwość przejęcia gospodarstwa rolnego na własność Skarbu Państwa w drodze decyzji Prezesa Agencji Własności Rolnej Skarbu Państwa, na wniosek rolnika, który nie miał możliwości przekazania całości lub części gospodarstwa rolnego na warunkach określonych w ustawie. Przejęcie następowało nieodpłatnie i dotyczyło jedynie nieruchomości wchodzących w skład gospodarstw wolnych od obciążeń, z wyjątkiem służebności gruntowych.

Wysokość renty strukturalnej wynosiła $150 \%$ emerytury podstawowej, a gdy do świadczenia uprawnieni byli zarówno rolnik, jak i jego małżonek - każdemu z nich przysługiwało w wysokości $150 \%$ emerytury podstawowej (art. 11, ust. 1 i 2). Rentę tę wypłaca się do osiągnięcia wieku emerytalnego lub do chwili nabycia praw do świadczeń emerytalno-rentowych, nie dłużej jednakże niż przez 5 lat (art. 14).

Ustawa ta obwiązywała w latach 2002-2004 i w oparciu o nią w roku 2002 złożono 1200 wniosków o rentę, natomiast po ich weryfikacji wydano 750 postanowień o spełnieniu warunków, przy czym z tej liczby rentę wypłaca się jedynie 460 osobom, w roku 2003 złożono około 600 wniosków. ${ }^{10}$ Dane te świadczą, że stosunkowo niski poziom rent strukturalnych nie stanowił wystarczającej motywacji dla rolników. Poza tym ustawa zawierała inne rygorystyczne postanowienie podporządkowane nadrzędnemu celowi strukturalnemu. Dotyczyły one przede wszystkim wy-

10 R. Budzinowski, Przekazanie gospodarstwa rolnego za rentę strukturalną w praktyce notarialnej, „Rejent” 2004, nr 10, s. 47-48. 
mogu powiększenia gospodarstwa do minimum 15 ha oraz dolnej granicy 3 ha przekazywanego gospodarstwa.

W latach 2004-2006 renty strukturalne funkcjonowały w oparciu o:

- ustawę z dnia 28 listopada 2003 r. o wspieraniu rozwoju obszarów wiejskich ze środków pochodzących z sekcji gwarancji Europejskiego Funduszu Orientacji i Gwarancji Rolnej, ${ }^{11}$

- Plan Rozwoju Obszarów Wiejskich,

- rozporządzenie Rady Ministrów z 30 kwietnia 2004 r. w sprawie szczegółowych warunków i trybu udzielenia pomocy na uzyskanie rent strukturalnych objętej planem rozwoju obszarów wiejskich. ${ }^{12}$

Plan Rozwoju Obszarów Wiejskich opracowany na podstawie wyżej wskazanej ustawy zakładał, że działanie „Renty strukturalne” miało na celu zapewnienie dochodu rolnikom, którzy zdecydują się zrezygnować z prowadzenia działalności rolniczej w gospodarstwie rolnym. Działanie skierowane było do osób w wieku przedemerytalnym, które ukończyły 55 lat, podlegały ubezpieczeniu społecznemu rolników, prowadziły działalność rolniczą w gospodarstwie o powierzchni co najmniej 1 ha przez co najmniej 10 lat (w tym co najmniej przez 5 lat były ubezpieczone w KRUS) i zdecydowały się je przekazać w celu poprawy żywotności ekonomicznej gospodarstwa innemu rolnikowi lub następcy, albo na rzecz Skarbu Państwa lub na cele związane z ochroną środowiska i zalesienie.

Duże znaczenie w nowych rentach strukturalnych przypisano funkcji socjalnej, ponieważ w miarę wysokie świadczenie mogło zabezpieczyć potrzeby bytowe rolnika i jego małżonka, jego wysokość, jak wskazał PROW, stanowiło rekompensatę utraconych wskutek przekazania gospodarstwa rolnego dochodów. Wysokość renty wraz z przystępnymi warunkami przyznawania określała stopień realizacji funkcji strukturalnej renty w świetle obowiązujących regulacji prawnych.

Zgodnie z rozporządzeniem renty strukturalne zachęcały rolników do zaprzestania prowadzenia działalności rolniczej w wieku przedemerytalnym i przekazania gospodarstw rolnych na rzecz młodych rolników lepiej wykwalifikowanych. Działanie to miało na celu poprawę żywotności gospodarstw, umożliwienie przekazu ich na cele pozarolnicze, gdy działalność rolnicza nie mogła być prowadzona w zadawalających ekonomiczne warunkach oraz zapewnienie rolnikom źródła dochodu po zaprzestaniu działalności gospodarczej. ${ }^{13}$ Renty strukturalne adresowane były do rolników w wieku przedemerytalnym podlegającym ubezpieczeniu społecznemu 
Renty strukturalne jako instrument poprawy struktury obszarowej rolnictwa...

rolników, którzy prowadzą działalność rolniczą w gospodarstwie będącym ich własnością (lub będących własnością ich małżonka), i którzy przekażą posiadane gospodarstwo innemu rolnikowi lub następcy, a wyniku tego przekazania żywotność ekonomiczna gospodarstwa ulegnie poprawie.

Żywotność ekonomiczna gospodarstwa uległa poprawie, jeżeli:

grunty przekazanego gospodarstwa zostały przejęte na powiększenie gospodarstwa rolnego innego rolnika (lub kilku rolników), który spełnia następujące przesłanki:

- był młodszy od przekazującego,

- posiadał kwalifikacje do przekazania działalności rolniczej,

- nie miał ustalonego prawa do emerytury lub renty z ubezpieczenia społecznego,

- zobowiązał się do prowadzenia działalności rolniczej na przejętych gruntach przez co najmniej 5 lat,

- grunty wchodzące w skład przekazanego gospodarstwa zostały przejęte w całości przez następcę, który nie ukończył 40. roku życia i spełnia pozostałe wyżej wymienione warunki,

- grunty wchodzące w skład gospodarstwa rolnego mogły być nabyte również:

- nieodpłatnie na Skarb Państwa w drodze decyzji Prezesa Agencji Nieruchomości Rolnych,

- W sposób trwały na cele związane z ochroną środowiska przez osobę prawną lub jednostkę organizacyjną nieposiadającą osobowości prawnej, zgodnie z ustawą o ochronie przyrody,

- w sposób trwały do zalesienia przez osobę fizyczną, prawną lub jednostkę organizacyjną nieposiadającą osobowości prawnej zgodnie z miejscowym planem zagospodarowania przestrzennego.

Renta strukturalna przysługiwała rolnikowi, który:

- ukończył 55 lat i nie osiągnął jeszcze wieku emerytalnego (mężczyzna - 65 lat, kobieta - 60 lat),

- prowadził działalność rolniczą na własny rachunek w gospodarstwie rolnym przez co najmniej 10 lat $\mathrm{i} \mathrm{w}$ tym okresie podlegał ubezpieczeniu emerytalno-rentowemu rolników przez okres co najmniej 5 lat,

- przekazal posiadane gospodarstwo rolne o powierzchni nie mniejszej niż 1 ha UR,

- zaprzestał prowadzenia wszelkiej działalności rolniczej, 
- wymagania dotyczące rolnika stosuje się odpowiednio do jego małżonka.

Gospodarstwo rolne mogło być przekazane w sposób trwały lub w formie umowy dzierżawy zawartej na okres co najmniej 10 lat. Umowa ta musiała być sporządzona w formie aktu notarialnego lub zarejestrowana w ewidencji gruntów i budynków. Za przekazanie gospodarstwa rolnego w sposób trwały uważano odpłatne i nieodpłatne przeniesienie prawa własności w drodze umowy sporządzonej w formie aktu notarialnego. Przekazanie gospodarstwa na rzecz innego rolnika mogło mieć formę trwałą lub w drodze umowy dzierżawy, natomiast w przypadku przekazania gospodarstwa zstępnemu, pasierbowi, osobie pozostającej we wspólnym gospodarstwie domowym, małżonkowi gospodarstwo musiało być przekazane w sposób trwały.

Wysokość renty strukturalnej stanowiło $210 \%$ najniższej emerytury. Wraz ze zwiększeniami nie mogła natomiast przekroczyć $440 \%$ najniższej emerytury.

Przysługiwały do niej dodatki:

1) z tytułu trwałego przekazania gospodarstwa o obszarze przynajmniej 3 ha UR, a zatem z wyłączeniem dzierżawy, w wysokości 50\% najniższej emerytury;

2) na małżonka w wysokości $60 \%$ najniższej emerytury;

3) za każdy przekazany trwale pełen hektar użytków rolnych powyżej 3 ha UR na powiększenie innego gospodarstwa w wysokości 3\% najniższej emerytury;

4) za każdy przekazany trwale pełen hektar użytków rolnych powyżej 3 ha UR na powiększenie innego gospodarstwa prowadzonego przez rolnika, który nie ukończył 40 lat w wysokości 3\% najniższej emerytury.

Dwa ostatnie zwiększenia uzależnione od obszaru użytków rolnych przysługiwały maksymalnie za 20 ha.

Rentę strukturalną wypłaca się jako świadczenie miesięczne przez maksymalny okres 10 lat. Jeżeli w czasie wypłaty renty uprawniony nabędzie prawo do emerytury z ubezpieczenia społecznego, rentę pomniejsza się o kwotę wypłacanej emerytury.

Renty w oparciu o to rozporządzenie cieszyły się dużo większym uznaniem u rolników, czego dowodem jest, że w latach 2004-2006 złożonych zostało 56273 wniosków, na podstawie, których przekazanych zostało 52 tys. gospodarstw. ${ }^{14}$

System Informacji Zarządczej ARiMR, 2007. 
Renty strukturalne jako instrument poprawy struktury obszarowej rolnictwa...

Od roku 2007 obowiązuje nowe rozporządzanie regulujące instytucję rent strukturalnych na lata 2007-2013. Jest to: rozporządzenie w sprawie szczegółowych warunków i trybu przyznawania pomocy finansowej w ramach działania „Renty strukturalne" objętego Programem Rozwoju Obszarów Wiejskich na lata 2007-2013, ${ }^{15}$ które po miesiącu zostało znowelizowane. ${ }^{16}$

Nowością w programie rent strukturalnych jest podwyższenie minimalnej normy obszarowej dostępu do programu do poziomu 3 ha UR, a więc podobnie jak w przepisach z 2001 r. Od tej zasady przewidziano wyjątki dla województw, w których ustawodawca dostrzega potrzebę intensywniejszego oddziaływania. Dotyczy to województw: małopolskiego, podkarpackiego, śląskiego i świętokrzyskiego, gdzie minimalny obszar umożliwiający skorzystanie ze świadczeń wynosi 1 ha UR.

Rozporządzenie wprowadziło również zmiany w zakresie przekazywania gruntów. Dotychczas nie miała znaczenia powierzchnia powiększanych gospodarstw, natomiast obecnie przy przekazaniu gospodarstwa następcy jego powierzchnia musi się mieścić co najmniej w średniej dla województwa położenia gospodarstwa lub w średniej dla kraju - jeśli średnia województwa jest od średniej krajowej wyższa. Dotyczy to również przekazania gruntów na powiększenie gospodarstwa, przy czym bierze się tu pod uwagę powierzchnię powiększonego gospodarstwa lub gospodarstw. W nowych rozwiązaniach zrezygnowano także z możliwości wydzierżawienia gruntów, a zatem konieczne jest wyzbycie się ich własności.

Wprowadzone zmiany dotyczą również osoby przejmującej grunty. Jeśli jest osobą fizyczną - rolnikiem już prowadzącym gospodarstwo, koniecznym jest spełnienie kryterium wieku. Chodzi o to, aby rolnik ten nie ukończył 50 lat. Ponadto, oprócz zobowiązania się do prowadzenia działalności rolniczej przez 5 lat, zarówno następca, jak i rolnik muszą dokonać rejestracji w ewidencji producentów rolnych, o ile rolnik nie był tam dotychczas zarejestrowany. W zakresie kwalifikacji rolniczych, wymogi zostały określone w sposób adekwatny do systemu szkolnictwa po reformie oświaty. W stosunku do osób prawnych, jako przejmujących wprowadzono zakaz przejęcia przez jednostki sektora finansów publicznych.

Istotnej zmianie uległa także wysokość świadczenia i jest to zmiana zdecydowanie mniej korzystna dla rolników. Podstawowa wysokość świadczenia wynosi $150 \%$ najniższej emerytury. Istnieje dodatek do świadczenia w postaci dodatku dla małżonka w wysokości $100 \%$ kwoty najniższej emerytury. System przewiduje również zwiększenie za przekazanie gospodarstwa rolnego osobie w wieku 40 lat o łącznej powierzchni UR większej niż 10 ha w wysokości 15\% najniższej emerytury. Zatem całkowita kwota świadczenia nie przekroczy 265\% najniższej emerytury. Brak jakichkolwiek zwiększeń powierzchniowych. Zwiększenia z tytułu prze- 
niesienia własności nieruchomości zlikwidowano ze względu na brak możliwości wydzierżawienia gruntów.

Analiza obowiązujących regulacji prawnych w zakresie rent strukturalnych wykazuje, że istniały i istnieją obecnie istotne różnice w programach rent. Wynikają one z różnych priorytetów jakie przypisuje się rentom. W rozwiązaniach z $2001 \mathrm{r}$. priorytetem był cel strukturalny, później zaakcentowano cel socjalny, chociaż element strukturalny pozostawał nadal widoczny, a obecnie rozporządzenie MRiRW nie wskazuje bezpośrednio na zadania socjalne systemu rentowego, na co zapewnie wpływ ma rozporządzenie Rady (WE) $1689 / 2005 .{ }^{17} \mathrm{~W}$ związku z tym różnice dotyczyły powierzchni gospodarstw uprawnionych do programu rent. Ze względu na priorytety ustawy z $2001 \mathrm{r}$. było to 3 ha, w rozporządzeniu z $2004-1$ ha, natomiast obecnie jest to 3 ha, z tym że w przypadku gospodarstw położonych w woj. małopolskim, podkarpackim, śląskim i świętokrzyskim - co najmniej 1 ha. Na gruncie omawianych regulacji prawnych można wskazać na różne sposoby dysponowania gospodarstwem, a mianowicie w rozwiązaniach z $2001 \mathrm{r}$. i obecnie nie istnieje możliwość dzierżawy gruntów. Pojawiła się ona w uregulowaniach z 2004 r. w których także nie wskazano minimalnej powierzchni powiększonego gospodarstwa, a na gruncie ustawy obszar ten musiał wynosić minimum 15 ha.

W nowym systemie rent strukturalnych przy przekazywaniu gospodarstwa następcy, jego powierzchnia musi się mieścić co najmniej w średniej dla województwa lub kraju.

Ponadto renty strukturalne z 2004 r. cechował zdecydowanie wyższy poziom świadczeń wynikający ze znacznie wyższej kwoty bazowej oraz rozbudowanego systemu dodatków, w tym obszarowych związanych z osobą przejmującą. Inne były i są obecnie źródła finansowania systemu rent strukturalnych - koszty ustawy obciążają w całości budżet państwa, natomiast regulacje z 2004 r. i 2007 r. w znacznej części są współfinansowane ze środków wspólnotowych.

\section{Wpływ rent strukturalnych na poprawę struktury obszarowej i przyspieszenie wymiany pokoleń $w$ rolnictwie}

Założenia rent strukturalnych zweryfikowała praktyka gospodarcza. Badania wykazały, że zainteresowanie rentami strukturalnymi w oparciu o ustawę było znikome, co zapewnie wynikało ze stosunkowo niskiego poziomu rent, który nie stanowił wystarczającej motywacji dla rolników, jak również z dość rygorystycznych postanowień podporządkowanych nadrzędnemu celowi strukturalnymi. Natomiast badania w zakresie realizacji programu rent w latach 2004-2006 wykazały, 
Renty strukturalne jako instrument poprawy struktury obszarowej rolnictwa...

że w programie udział wzięło znacznie więcej rolników - ponad 56 tys., przekazując ponad 52 tys. gospodarstw, co było zapewnie efektem wysokości świadczeń oraz znacznych złagodzeń uczestnictwa w tym programie.

Renty strukturalne z założenia w swej konstrukcji prawnej są instrumentem poprawy struktury obszarowej, natomiast w jakim stopniu wpływają praktycznie na kształtowanie pożądanej struktury i wymianę pokoleń, wykazały badania empiryczne zawarte w pracy doktorskiej przygotowanej pod moim promotorstwem pt. „,Renty strukturalne jako instrument poprawy struktury obszarowej i powiększenia wymiany pokoleń w rolnictwie", które częściowo zostały wykorzystane w artykule. ${ }^{18}$

Badaniami empirycznymi objęto 222 gospodarstwa położone na obszarze województwa łódzkiego ze szczególnym uwzględnieniem powiatu wieluńskiego, które spełniały kryteria dostępu do programu rent na podstawie rozporządzenia z 2004 r. Gospodarstwa poddane badaniom stanowiły 90,1\% ogólnej liczby gospodarstw spełniających kryteria dostępu.

Do analizy gospodarstwa te grupowano na sześć grup obszarowych: I 1-3 ha, II 3-7 ha, III 7-10 ha. IV 10-15 ha, V 15-20 ha, VI powyżej 20 ha. Podział ten zdeterminowały przepisy dotyczące rent strukturalnych w zakresie zwiększeń z tytułu przekazywanych gruntów, ponadto dał lepszy obraz programu rent strukturalnych i jego wpływu na poprawę struktury obszarowej i przemianę pokoleń.

Zgodnie z PROW na lata 2004-2006 podstawowymi celami rent strukturalnych była poprawa struktury obszarowej gospodarstw rolnych, zapewnienie dochodu rolnikom starszym wiekiem odchodzących z aktywności zawodowej w rolnictwie, wspieranie procesu wymiany pokoleń w rolnictwie, a także przeznaczenie gruntów rolnych na cele nierolnicze, jeżeli ich dalsze rolnicze wykorzystanie nie jest ekonomicznie uzasadnione. W efekcie ustawodawca wskazał funkcję strukturalną dla rent. W funkcji tej mieści się również obniżenie wieku osób prowadzących gospodarstwa oraz przeznaczenie gruntów na cele nierolnicze. ${ }^{19}$ Uzyskanie pożądanych efektów strukturalnych jest nieodzownie związane z funkcją socjalną systemu rent, ponieważ wysokość świadczeń w dużym stopniu decyduje o zainteresowaniu rentami.

Wyniki badań wykazały, że wyliczone wysokości roczne świadczeń rentowych - dla porównania w oparciu o przepisy z 2001, 2004 i 2007 roku - różniły się znacząco co niewątpliwie wpływało na relacje funkcji socjalnej poszczególnych programów rent (tabela 1).

18 M. Orlewski, Renty strukturalne jako instrument poprawy struktury obszarowej i przyspieszenia wymiany pokoleń w rolnictwie. Rozprawa doktorska przegotowana pod kierunkiem B. Tańskiej-Hus, Uniwersytet Przyrodniczy we Wrocławiu, 2008.

19 S. Paszkowski, Mechanizmy wymiaru świadczeń a cele instrumentu rent strukturalnych, „Wieś i Rolnictwo” 2007, nr 3, s. 137 . 
Bożena Tańska-Hus

Tabela 1. Wysokość rent strukturalnych w oparciu o regulacje z 2001, 2004 i 2007 roku²0

\begin{tabular}{|c|c|c|c|c|c|}
\hline \multicolumn{3}{|c|}{ Wyszczególnienie } & Ustawa & Rozporzadzenie & Rozporzadzenie \\
\hline \multirow{12}{*}{$\begin{array}{l}\text { Grupa } \\
\text { obszarowa }\end{array}$} & \multirow{2}{*}{$\stackrel{\text { I }}{1-3 \mathrm{ha}}$} & zł/gospodarstwo & 10980 & 12016 & 9829 \\
\hline & & $\%$ & 91,4 & 100,0 & 81,9 \\
\hline & \multirow{2}{*}{$\begin{array}{c}\text { II } \\
3-4 \text { ha }\end{array}$} & zł/gospodarstwo & 12995 & 15833 & 11172 \\
\hline & & $\%$ & 82,0 & 100,0 & 70,5 \\
\hline & \multirow{2}{*}{$\begin{array}{c}\text { III } \\
7-10 \text { ha }\end{array}$} & zł/gospodarstwo & 12249 & 15845 & 10675 \\
\hline & & $\%$ & 77,3 & 100,0 & 67,3 \\
\hline & \multirow{2}{*}{$\begin{array}{c}\text { IV } \\
10-15 \text { ha }\end{array}$} & zł/gospodarstwo & 13317 & 16280 & 11387 \\
\hline & & $\%$ & 81,8 & 100,0 & 69,9 \\
\hline & \multirow{2}{*}{$\begin{array}{c}V \\
15-20 \text { ha }\end{array}$} & zł/gospodarstwo & 13906 & 17187 & 10664 \\
\hline & & $\%$ & 80,9 & 100,0 & 62,0 \\
\hline & \multirow{2}{*}{$\begin{array}{c}\text { VI } \\
\text { powyżej } 20 \text { ha }\end{array}$} & zł/gospodarstwo & 14362 & 16823 & 12084 \\
\hline & & $\%$ & 85,4 & 100,0 & 71,8 \\
\hline
\end{tabular}

${ }^{*}$ Regulacje $2004=100 \%$

Jak wynika z tabeli 1 , renta strukturalna wyliczona w oparciu o przepisy ustawy z 2001 r. stanowiła od ponad 77\% w grupie III do ponad 91\% w grupie I - renty z 2004 r. Najmniejsza różnica występowała w grupie I, gdzie świadczenie było mniejsze tylko o $8 \%$ w porównaniu do roku 2004. Wynikało to z faktu, iż nie występowały w I grupie w programie z 2004 r. zwiększenia powierzchniowe z tytułu przekazanych gruntów. Największa różnica w poziomie świadczeń 18-20\% występowała w gospodarstwach grupy II, IV i V, co spowodowane było odmiennymi rozwiązaniami w zakresie zwiększeń obszarowych w ustawie z 2001 r. i rozporządzeniu z 2004 r. Natomiast w oparciu o przepisy z 2007 r. renta strukturalna stanowiła od $62 \%$ do ponad $81 \%$ renty z 2004 r. Najmniejsza różnica występowała w grupie I gdzie wysokość świadczenia była o 18\% niższa od świadczenia z 2004 r., natomiast $\mathrm{w}$ pozostałych grupach obszarowych różnice były dużo większe i wynosiły od $28 \%$ do $38 \%$. Można uzasadnić to tym, że w nowych przepisach prawnych nie przewidziano zwiększeń obszarowych a ponadto obniżono wysokość renty do $150 \%$ emerytury podstawowej. 
Renty strukturalne jako instrument poprawy struktury obszarowej rolnictwa...

Przedstawione dane wskazują, że obecnie obowiązujące przepisy są mniej korzystne pod względem wysokości świadczeń rentowych. W porównaniu do roku 2001 renty te są średnio niższe o 14\%, natomiast w porównaniu do 2004 r. aż o $29 \%$. Znacznie słabsza realizacja funkcji dochodowej może wpływać na mniejsze zainteresowanie rentami, a w konsekwencji na realizację funkcji strukturalnej programu rent.

Aby ocenić atrakcyjność rent strukturalnych, porównano wysokość rent z poszczególnych lat do wyliczonego dochodu rolniczego netto uzyskiwanego przez badane gospodarstwa w okresie obowiązywania rozporządzenia z 2004 r. (tabela 2).

Tabela 2. Wysokość rent strukturalnych do poziomu dochodu rolniczego netto ${ }^{21}$

\begin{tabular}{|c|c|c|c|c|c|c|}
\hline \multicolumn{3}{|c|}{ Wyszczególnienie } & \multirow{2}{*}{$\begin{array}{c}\text { Ustawa } \\
\text { z } 2001 \mathrm{r} . \\
10980\end{array}$} & \multirow{2}{*}{$\begin{array}{c}\text { Rozporzadzenie } \\
\text { z } 2004 \text { r. } \\
12016\end{array}$} & \multirow{2}{*}{$\begin{array}{c}\text { Rozporzadzenie } \\
\text { z } 2007 \text { r. } \\
9829\end{array}$} & \multirow{2}{*}{$\begin{array}{c}\begin{array}{c}\text { Dochód } \\
\text { rolniczy }\end{array} \\
\text { netto w } 2004 \text { r. } \\
7118\end{array}$} \\
\hline \multirow{12}{*}{$\begin{array}{l}\text { Grupa } \\
\text { obszarowa }\end{array}$} & \multirow{2}{*}{$\stackrel{\text { I }}{1-3 \text { ha }}$} & zł/gospodarstwo & & & & \\
\hline & & $\%$ & 154,3 & 168,8 & 138,0 & 100,0 \\
\hline & \multirow{2}{*}{$\begin{array}{c}\text { II } \\
\text { 3-7 ha }\end{array}$} & zł/gospodarstwo & 12995 & 15833 & 11172 & 9416 \\
\hline & & $\%$ & 138 & 168,1 & 118,6 & 100,0 \\
\hline & \multirow{2}{*}{$\begin{array}{c}\text { III } \\
7-10 \text { ha }\end{array}$} & zł/gospodarstwo & 12249 & 15845 & 10675 & 12720 \\
\hline & & $\%$ & 96,3 & 124,5 & 83,9 & 100,0 \\
\hline & \multirow{2}{*}{$\underset{10-15}{\text { IV }}$} & zł/gospodarstwo & 13317 & 16280 & 11387 & 32822 \\
\hline & & $\%$ & 40,5 & 49,6 & 34,6 & 100,0 \\
\hline & \multirow{2}{*}{$\begin{array}{c}V \\
15-20 \text { ha }\end{array}$} & zł/gospodarstwo & 13906 & 17187 & 10664 & 22976 \\
\hline & & $\%$ & 60,5 & 74,8 & 46,4 & 100,0 \\
\hline & \multirow{2}{*}{$\begin{array}{c}\text { VI } \\
\text { powyżej } \\
20 \text { ha }\end{array}$} & zł/gospodarstwo & 1436 & 16823 & 12084 & 60000 \\
\hline & & $\%$ & 23,9 & 28,1 & 20,1 & 100,0 \\
\hline
\end{tabular}

${ }^{*}$ Dochód rolniczy netto $=100 \%$

Z danych zawartych w tabeli 2 wynika, że wysokość renty strukturalnej z 2001 r. stanowiła od $24 \%$ do $154 \%$ dochodu rolniczego netto, przy czym w grupach od III do VI wysokość renty była mniejsza od osiąganych przez rolników dochodów. Zdecydowanie niską rekompensatę utraconych dochodów renta stanowiła w grupach IV, V i VI. W przypadku obecnie obowiązującego rozporządzenia wysokość wyliczonej renty stanowi od $20 \%$ do $138 \%$ dochodu rolniczego netto, przy czym przedział pełnej rekompensaty dochodu rolniczego przebiega podobnie jak w przypadku 
przepisów z 2001 r. Jednakże różnice występujące w grupach III-VI są zdecydowanie wyższe i kształtują się na poziomie $80 \%$ w stosunku do dochodu. Generalnie tylko w gospodarstwach o obszarze do 10 ha pod rządami wszystkich regulacji poziom rent strukturalnych znacznie przekroczył dochód rolniczy netto i to pomimo barku zwiększeń obszarowych w grupie gospodarstw 1-3 ha.

Oprócz funkcji dochodowej renty strukturalne realizują funkcje strukturalne, w wyniku których ma nastąpić poprawa struktury obszarowej gospodarstw rolnych. Realizowana jest ona w drodze przekazywania gospodarstw na rzecz innych rolników, przede wszystkim młodszych. Rozporządzenie z 2004 r. przewiduje dwie formy przekazania: trwałe przekazanie i dzierżawę.

Jak wykazały badania wśród respondentów badanych gospodarstw wykazujących chęć skorzystania z renty strukturalnej, większość decydowała się na trwałe rozporządzenie gospodarstwem (tabela 3). Wpływ na to miała miedzy innymi możliwość skorzystania z dodatkowych zwiększeń świadczenia z tytułu wyzbycia się własności gruntów (3\% podstawy wymiaru renty za każdy ha UR).

Tabela 3. Formy rozporządzania gruntami w $(\%)^{22}$

\begin{tabular}{||l|c|c|c|c|c|c||}
\hline \multirow{2}{*}{ Wyszczególnienie } & \multicolumn{7}{|c||}{ Grupa obszarowa } \\
\cline { 2 - 7 } & $\begin{array}{c}\text { I } \\
1-3 \text { ha }\end{array}$ & $\begin{array}{c}\text { II } \\
3-7 \text { ha }\end{array}$ & $\begin{array}{c}\text { III } \\
7-10 \text { ha }\end{array}$ & $\begin{array}{c}\text { IV } \\
10-15 \text { ha }\end{array}$ & $\begin{array}{c}\text { V } \\
15-20 \text { ha }\end{array}$ & $\begin{array}{c}\text { VI } \\
\text { powyżej 20 ha }\end{array}$ \\
\hline Trwałe przekazanie & 89,5 & 92,6 & 84,8 & 85,3 & 100,0 & 100,0 \\
\hline Dzierżawa & 10,5 & 7,4 & 15,2 & 14,7 & - & 100,0 \\
\hline Razem & 100,0 & 100,0 & 100,0 & 100,0 & 100,0 & 100 \\
\hline \hline
\end{tabular}

Jak wynika z danych zawartych w tabeli 3, wszyscy respondenci z gospodarstw większych obszarowo (grupa V i VI) zdecydowali się trwale przekazać gospodarstwa, zwłaszcza że przejmującymi grunty były osoby blisko spokrewnione (tabela 4). W pozostałych grupach obszarowych na trwałe przekazanie gospodarstw zdecydowało się ponad $85 \%$. Natomiast dzierżawa jako drugi sposób rozdysponowania gruntami stanowiła od ponad $7 \%$ do $15 \%$.

Z punktu widzenia wpływu rent strukturalnych na poprawę struktury obszarowej rolnictwa znaczenie ma niewątpliwie zadysponowanie gospodarstwem jako całością lub w częściach. W niektórych sytuacjach rozdysponowanie gospodarstwem było uwarunkowane osobą przejmującą, ponieważ przekazanie gospodarstwa na rzecz następcy mogło być jedynie w całości (tabela 4). 
Renty strukturalne jako instrument poprawy struktury obszarowej rolnictwa...

Tabela 4. Kategorie osób przejmujących grunty w $(\%)^{23}$

\begin{tabular}{|l|c|c|c|c|c|c|}
\hline \multirow{2}{*}{ Wyszczególnienie } & \multicolumn{5}{|c|}{ Grupy obszarowe } \\
\cline { 2 - 7 } & I 1-3 ha & II 3-7 ha & III 7-10 ha & IV 10-15 ha & V15-20 ha & $\begin{array}{c}\text { VI powyżej } \\
20 \text { ha }\end{array}$ \\
\hline $\begin{array}{l}\text { Przekazanie } \\
\text { gruntów w tym: }\end{array}$ & 78,9 & 83,3 & 81,8 & 85,3 & 88,8 & 100,0 \\
\hline Następcy & 15,8 & 9,2 & 16,2 & 14,7 & - & - \\
\hline $\begin{array}{l}\text { Rolnikowi } \\
\text { już prowadzacemu } \\
\text { gospodarstwo }\end{array}$ & 5,3 & 7,5 & - & - & 11,2 & - \\
\hline $\begin{array}{l}\text { Rolnikowi jw. } \\
\text { młodszemu niż } \\
\text { 40 lat }\end{array}$ & 100,0 & 100,0 & 100,0 & 100,0 & 100,0 & 100,0 \\
\hline \begin{tabular}{l} 
Ogółem \\
\hline
\end{tabular}
\end{tabular}

Tabela 5. Przekazanie gruntów w całości lub części ${ }^{24}$

\begin{tabular}{|l|c|c|c|c|c|c||}
\hline \multirow{2}{*}{ Wyszczególnienie } & \multicolumn{5}{|c||}{ Grupy obszarowe } \\
\cline { 2 - 7 } & I 1-3 ha & II 3-7 ha & III 7-10 ha & IV 10-15 ha & V15-20 ha & $\begin{array}{c}\text { VI powyżej } \\
20 \text { ha }\end{array}$ \\
\hline $\begin{array}{l}\text { Przekazanie } \\
\text { w całości } \\
\text { gospodarstwa w (\%) }\end{array}$ & 100,0 & 94,4 & 88,8 & 88,2 & 88,8 & 100,0 \\
\hline $\begin{array}{l}\text { Przekazanie } \\
\text { gospodarstwa } \\
\text { w działkach w (ha) }\end{array}$ & - & 1,9 & 4,2 & 6,2 & 8 & - \\
\hline
\end{tabular}

Przeprowadzone badania wykazały, że wszyscy rolnicy w I grupie zdecydowali się przekazać gospodarstwa w całości na rzecz jednej osoby, co wynikało z powierzchni gospodarstw oraz z przepisów z 2004 r. przy czym 79\% zdecydowało się przekazać gospodarstwo następcy - osobie w wieku 40 lat rozpoczynającemu działalność na przejętych gruntach po raz pierwszy. Odsetek przekazujących gospodarstwo innemu rolnikowi prowadzącemu gospodarstwo i który nie ukończył 40. lat, a więc nabywcy najbardziej preferowanemu w rozporządzeniu z 2004 r., wynosił zaledwie 5,26\%, a na rzecz starszych rolników ponad $15 \%$ i w tym przypadku rozporządzenie gruntami mogło choć w znikomym znaczeniu wpłynąc na poprawę struktury obszarowej gospodarstw. Wśród rolników II grupy prawie 95\% zdecydowało się przekazać gospodarstwo w całości na rzecz jednej osoby - głównie następcy, natomiast we fragmentach (działkach) był to obszar średnio 1,9 ha. Ponadto około $8 \%$ rolników wyrażało chęć przekazania gospodarstwa rolnikom w wieku poniżej 40 lat. W tej grupie można zaobserwować istotny wpływ rent strukturalnych na wymianę pokoleń, gdzie odsetek nabywców w wieku poniżej 40 lat wynosił ponad $90 \%$. Z kolei w grupie obszarowej III i V ponad $88 \%$ rolników zdecydowało

23 Źródło: obliczenie własne na podstawie M. Orlewski, op. cit., s. 149.

24 Źródło: obliczenie własne na podstawie M. Orlewski, op. cit., s. 150. 
o rozporządzeniu gospodarstwami w całości na rzecz jednej osoby. W grupach tych w pozostałej sytuacji rozdysponowane nowo powstałe fragmenty stanowiły odpowiednio w grupie III $-4,2$ ha, a w grupie V -8 ha. Ponadto w grupie V $100 \%$ gruntów przeszło na rzecz rolników poniżej 40 lat, co w znacznym stopniu wpłynęło na zmniejszenie wieku osób prowadzących gospodarstwa, przy czym należy pamiętać, że ponad $88 \%$ to grunty przejęte w całości przez jedną osobę - następcę, a więc sytuacja obszarowa nie ulega zmianie. Rolnicy grupy VI w całości wyrazili zgodę przekazania gospodarstw w całości na rzecz jednej osoby - następcy i w tej sytuacji struktura obszarowa przekazywanych gospodarstw nie uległa zmianie, ale i też nie nastąpiło jej pogorszenie (tabela 5).

Dane te wskazują na znikomy wpływ rent na poprawę struktury obszarowej gospodarstw. Również i w tej grupie w zasadzie zachowane zostanie status quo w kwestii struktury obszarowej gruntów, natomiast podobnie jak w grupie $\mathrm{V}$ we wszystkich przypadkach zmniejszył się poniżej 40. roku życia wiek rolników - kierowników gospodarstw.

Reasumując, badania wykazały, że renty strukturalne wprowadzone rozporządzeniem z 2004 r. spełniły bardziej funkcję socjalną, wpłynęły na przyspieszenie wymiany pokoleń, natomiast nie mają istotnego wpływu na poprawę struktury obszarowej gospodarstw. Świadczy o tym fakt, że głównym sposobem rozdysponowania gruntów było rozdysponowanie na rzecz następcy, natomiast udział gruntów na powiększenie istniejących gospodarstw był znikomy. Dla praktyki taka interpretacja nie jest jednak jednoznacznie negatywna, bowiem przekazanie gospodarstwa jednemu następcy wprawdzie nie poprawia struktury obszarowej, ale zapobiega dalszemu podziałowi ziemi pomiędzy ewentualnych spadkobierców, zapobiega więc postępującemu rozdrobnieniu, a tym samym zapobiega pogorszeniu struktury obszarowej. 
Renty strukturalne jako instrument poprawy struktury obszarowej rolnictwa...

\section{EARLY RETIREMENTS AS AN INSTRUMENT OF AGRICULTURAL AREA STRUCTURE IMPROVEMENT AND GENERATION CHANGE ACCELERATION}

Key words: common agricultural policy, early retirement, generation exchange.

Early retirements from farming is one of the instrument of agricultural structure improvement and generation change acceleration introduced to the EU legislation by the Council Regulation (EEC) No 2079/92 and 1257/99, transferred to the Polish law. In the article the EU and the Polish binding legal solutions in the field of early retirements from farming were analyzed. The Author pointed out advantages and disadvantages as well as provided an assessment of impact possibilities that early retirements can have on agricultural area structure improvement and on generation exchange acceleration due to 2004 regulation.

It was pointed out that early retirements introduced by this regulation played rather social role as they influenced on the generation exchange acceleration but they did not have any relevant effect on the farm structure improvement. 